\title{
PERSONALISED DIET IMPROVE INTESTINE MICROBIOTA AND METABOLISM OF OBESE RATS
}

\author{
V. V. BATI ${ }^{\boxplus}$, T. V. MELESHKO ${ }^{1}$, O.V. PALLAH ${ }^{1}$, \\ I. P. ZAYACHUK ${ }^{2}$, N. V. BOYKO ${ }^{1}$ \\ ${ }^{1} R D E$ Centre of Molecular Microbiology and Mucosal Immunology, \\ Uzhhorod National University, Ukraine; \\ ${ }^{2}$ Department of Physiology and Pathophysiology, \\ Uzhhorod National University, Ukraine; \\ 凶e-mail: victoria.bati@uzhnu.edu.ua
}

Received: 25 April 2020; Accepted: 07 July 2021

Recent research on human microbiome provide opportunities to develop functional foods of new generation that can regulate intestinal microbiota and the biochemical status of the individual. The aim of the study was to determine the effect of individually designed nutrition on the intestinal microbiota and metabolic parameters of rats. Outbred laboratory rats with obesity were randomly divided into 9 groups $(n=12)$ depending on the type of food ingredients taken orally for three months. The ratio of the intestinal commensal microorganisms main groups, as well as the lipid profile and the content of glucose, urea, calcium in the serum of animals were determined. It was shown that cholesterol level in the serum was reduced in experimental groups after consumption of lactobacilli suspension, blueberry juice, fermented milk drink based on lactobacilli, fermented milk drink with blueberry juice, sauerkraut. In most cases, the gut microbiome of experimental animals was characterized by a consistently high level of lacto and other beneficial bacteria and decreased amount of opportunistic microorganisms at the end of the experiment compared with animals in the control group. Based on the obtained data, we first proposed the principles of creating functional products by synergistically combining components of edible plants that act as prebiotics and microorganisms that act as probiotics for personalized use, targeted correction of intestinal microbiome and prevention of noncommunicable diseases.

Ke ywo rds: functional foods, lipid profile, cholesterol, obesity, intestine microbiota, prebiotic and probiotic components.

$\mathrm{T}$ he fact that co-evolutionary relationships between nutrition, gut microbiota, stress, lifestyle, and environmental factors lead to epigenetic influence on human health outcomes is already widely accepted [1, 2]. Nowadays, it is obvious that changes in gut microbiota often act as a trigger of noncommunicable diseases connected to low-grade inflammation and metabolic disorders, such as obesity, type 2 diabetes (T2D), cardiovascular diseases, and others. Recently, clear evidence that patients with such metabolic diseases face changes in specific groups of gut microbiome has been reported. In addition, most of the mechanisms of commensal microorganisms' modulation of human health are being investigated [3-5]. For example, enteric carriage of a community of Clostridium species induces IL-10 secreting Foxp3 Tregs in the colon, probably via the induction of transforming growth factor beta [6].

Recent scientific advances point to the fact that low-grade inflammation is related to gut microbiota dysfunction caused by microorganism' imbalance and contributing to obesity. This is currently one of the most serious public health challenges worldwide because of its increasing prevalence and its contribution to a complex of symptoms collectively called the "metabolic syndrome" and other comorbidities, such as type 2 diabetes [7, 8]. Diabetic individuals have 
lower counts of Bifidobacterium and Faecalibacterium microbial representatives beneficial for gut [9]. The beneficial effect of the "healthy gut microbial composition" and microorganisms' ratio are reconsidered because of their different functional features [10].

Nowadays, one of the commonly known and most widely used approaches to correct human microbiota is to prescribe various biopharmaceuticals like pre-, pro-, and synbiotics, or pharmabiotics, if their efficacy is clinically proven. Among the numerous gut microbial species, certain commensal bacteria are known to provide health benefits to the host when administered in adequate amounts, and, as such, they are labeled "probiotics" [11]. In addition to the reported limited success of biopharmaceuticals' use [12] in medical practice, which is potentially increased through prescription personalization [13], in our opinion, the most promising is still a more integrated, "natural", and targeted prognostic correction of microbiota via the newly developed functional nutrition of new generation [14].

One of the recognized beneficial mechanisms of commensal gut microbiota effect on the host is the production of specific short-chain fatty acids (butyrate non acetate and propionate) during the fermentation of dietary fibers. These acids have multiple beneficial effects on the host's energy metabolism regulation on the whole: they not only improve gut condition, but also directly affect all the other peripheral tissues of the host, including muscles, liver, and nerves [15-17].

It has been proven that dietary microbiome adjustment prevents overweight and obesity. One of the good examples is the "Mediterranean diet" based on the use of bread, pasta, rice, corn porridge, cereals and potatoes, fruits, vegetables, legumes, olive oil, yogurt, and fish [18, 19]. However, data concerning its efficacy still requires further confirmation by properly arranged clinical trials [20].

Interestingly, individual members of the gut microbiome can also have profound effects on host mucosal homeostasis, and specific microbes have been found to promote inflammatory [21, 22] or anti-inflammatory $[23,24]$ responses in the gut [25]. Hence, the interaction between the microbiome and the gut immune system is crucial for the maintenance of mucosal homeostasis. For example, Bacteroides fragilis produces a polysaccharide A which induces Tregs that secrete IL-10 and inhibit gut inflammation [5, 26]. Additionally, B. fragilis can produce a-galactosylceramide (a-Gal-CerBf), a glycosphingolipid which is capable of binding CD1d and activating invariant natural killer T cells [27].

Microbiota of every individual is unique and has the function of modulating the immune system. Therefore, individually designed diets that take into account a person's characteristics and are able to prevent the development of infectious and diet-related somatic pathologies can be considered promising.

Modern food is considered not only as composition of nutrients. It must also comply with individual requirements and have a positive effect at the biochemical, cell, tissue, organ, and organism levels. For example, Chardonnay grape seed flour can modulate the gut microbiota while lowering excessive plasma cholesterol and improving the state of the vascular wall [28]. Moreover, it is better to choose food from a local source [29] so that it was ethnic, tasty, and cheap. If we know the key microorganisms or their associations that are markers of a certain disease, we may choose the food developed to specifically modulate gut microbiota.

The aim of this study was to investigate the impact of individually designed nutrition on gut microbiota and metabolism of rats.

\section{Materials and Methods}

Bacterial strains and animal groups. In the study, we used our original strains sequenced and documented in the Depositary of Microorganisms of the D.K. Zabolotny Institute of Microbiology and Virology of the NASU, namely: Lactobacillus casei IMB B-7412 (isolated from sauerkraut), Lactobacillus plantarum IMB B-7414 (isolated from sauerkraut), Lactobacillus paracasei IMB B-7483 (isolated from Sautéed pickled green beans), and L. plantarum KR-1 (isolated from Kvass southern). Bacterial strains were obtained from fermented products and were chosen based on their anti-inflammatory features, ability to specifically modulate local immune response, and regulate gut microbiota representatives, which was demonstrated in vitro [30]. Pro- and anti-microbial activity of the pre- and probiotic components of the complex novel foods was investigated in vitro [31, 32].

All experiments in rats were performed in accordance with the international principles outlined by the European Convention for the Protection of Vertebrate Animals Used for Experimental and Other Scientific Purposes (Strasbourg, 1986) signed by the Verkhovna Rada of Ukraine in 2002, 
Law of Ukraine No. 3447 - IV "On the Protection of Animals from Cruelty", meeting minutes of the Bioethics Commission of the Medical Faculty of the State University "Uzhhorod National University" (Minutes No. 1, dated May 24, 2019).

In this study, nine groups of 12 white laboratory rats aged 22-24 months, with male and female rats being equally presented in each group, were formed. For the experiments we have used rats additionally fed with a "fat-rich" diet (in analogues to high-fat diet rodent models [33]) for the induction of obesity. We have specifically chosen the old rat generation for the personalized diet experiments in order to address "age" relevant issues and to be able to provoke the "type 2 diabetes" like human condition connected with microbiome and metabolomic profile" that are relevant to chronic inflammation changes and which are often initiated in elderly people. In the experimental groups, each animal received tested ingredient(s) in the amount of $0.5 \mathrm{ml}$ daily during 12 weeks in addition to the standard food received by the control group. During the experiment, all animals were orally consuming different ingredient(s) depending on the experimental group: Group 1 suspension of lactobacilli (L. casei IMB B-7412, L. plantarum IMB B-7414, L. paracasei IMB B-7483, and L. plantarum KR-1); Group 2 - blueberry juice (Vaccinium murtillus); Group 3 - fermented milk drink with strains of lactobacilli (L. paracasei IMB B-7483, L. casei IMB B-7412, L. plantarum IMB B-7414, and L. plantarum KR-1) and blueberry juice (the ratio of the fermented drink and blueberry juice was 4:1); Group 4 - fermented milk drink with strains of lactobacilli (L. paracasei IMB B-7483, L. casei IMB B-7412, L. plantarum IMB B-7414, and $L$. plantarum KR-1) without plant components; Group 5 - sauerkraut juice with L. casei IMB B-7412 and L. plantarum IMB B-7414; Group 6 - persimmon juice (Diospyros kaki); Group 7 - lignin; Group 8 pectin (15\%); Group 9 - control group, standard vivarium diet food. A suspension of microorganisms was prepared daily before the administration using $48 \mathrm{~h}$ pure cultures of tested microorganisms taken at the concentration of no less than $1.5 \times 10^{8} \mathrm{CFU} / \mathrm{ml}$ according to McFarland. Body weight of each animal's group was determined twice, at the start and at the end of experiment (Table 1, Fig. 1).

Study of the biochemical and microbiological parameters. Before and after the gavage, the weight of the all the experimental animals was monitored and blood sampling was taken from the tail vein using the Microvette ${ }^{\circledR}$ capillary blood collection system for biochemical study. The lipid profile, namely total lipids, triglycerides, low-density lipoproteins (LDL), cholesterol, urea, calcium, and glucose, was measured by colorimetric analysis using ready-made reagents manufactured by "PhilisitDiagnostics,” LLC.

In order to detect changes in major gut microbiota representatives and their composition under the influence of tested ingredients of the newly developed functional nutrition in obese rats in real time,

Table 1. Initial body weight of selected rats

\begin{tabular}{c|cc}
\hline $\begin{array}{c}\text { Group } \\
\text { number }\end{array}$ & Group name & $\begin{array}{c}\text { Initial body } \\
\text { weight mean } \\
\pm \text { SD, g }\end{array}$ \\
\hline 1 & Suspension of lactobacilli* & $205.7 \pm 1.1$ \\
2 & Blueberry juice & $200.0 \pm 2.5$ \\
3 & Fermented milk drink with strains of lactobacilli* and blueberry juice & $193.0 \pm 0.1$ \\
4 & Fermented milk drink with strains of lactobacilli \\
5 & Sauerkraut juice with L. casei IMB B-7412 & $187.7 \pm 3.2$ \\
6 & and L. plantarum IMB B-7414 \\
7 & Persimmon juice (Diospyros kaki) & $191.7 \pm 1.2$ \\
8 & Lignin & $185.0 \pm 0.5$ \\
9 & Pectin & $188.7 \pm 1.2$ \\
\hline
\end{tabular}

Note: Lactobacilli strains suspension* includes beneficial stains with probiotical features, isolated from Black Sea region traditional food: L. casei IMB B-7412, L. plantarum IMB B-7414, L. paracasei IMB B-7483, L. plantarum KR-1, taken to experiment in amount of $1.5 \times 10^{8} \mathrm{CFU} / \mathrm{ml}$ 
the samples were taken on the third, seventh, $14^{\text {th }}$, $21^{\text {st }}, 28^{\text {th }}, 35^{\text {th }}, 42^{\text {nd }}, 49^{\text {th }}, 56^{\text {th }}, 63^{\text {rd }}, 70^{\text {th }}, 77^{\text {th }}, 84^{\text {th }}$, and $91^{\text {st }}$ days from the beginning of the experiment. Therefore, on every seventh day of the experiment $1 \mathrm{~g}$ of feces was collected from the experimental animals and mixed with $1 \mathrm{ml}$ of PBS. Ten-fold serial dilution of samples was performed and plated correspondingly on the chromogenic, typical, and selective growth media: MacConkey agar, Blood agar, Nutrient agar, Mannitol salt agar, Wilson-Blair agar, Sabouraud dextrose agar, Lactobacillus MRS agar, Bifidobacterium agar, Anaerobic blood agar, Bile esculin agar, Streptococcus selective agar, Bacteroides bile esculin agar (all above mentioned growth media produced by HiMedia Laboratories, India), UriSelect $^{\mathrm{TM}} 4$ Medium (Bio-Rad Laboratories, Inc, USA), or Blaurock semi-liquid modified hepatic medium (Liofilchem, Italy).

For Bacteroides' isolation, of $10^{-5}-10^{-7}$ dilutions of each sample, $10 \mu 1$ were plated on the surface of Bacteroides bile esculin agar and incubated for 4-5 days under anaerobic conditions. After microscopy, the morphology of the microorganisms was evaluated. Gram-negative polymorphic anaerobes can be preassigned to Bacteroides. Lactobacilli were isolated from $10^{-2}-10^{-8}$ dilutions. Seeding was carried out in the amount of $10 \mu \mathrm{l}$ on MRS broth or MRS agar and incubated for 2-3 days under anaerobic conditions.

Enterococci, staphylococci, and streptococci were isolated by plating $10 \mu \mathrm{l}$ of a $10^{-2}-10^{-8}$ dilution on bile esculin agar, mannitol salt agar, or streptococcus selection agar respectively and incubated at $37^{\circ} \mathrm{C}$ in a thermostat for $18-24 \mathrm{~h}$. Blood agar, nutrient agar, and UriSelect were also used for streptococci isolation. Preliminary differential diagnosis of Staphylococcus aureus was performed using tests for catalase, hemolytic, and coagulase activity.

Yeast-like fungi were isolated by plating the $10^{-2}-10^{-8}$ dilution on the surface of sabouraud dextrose agar. After 2-3 days, white-matte colonies were selected for identification. The total amount of aerobic bacteria and their hemolytic properties was determined by plating $10^{-5}$ and $10^{-7}$ suspension dilutions on blood agar. The total amount of enterobacteria was determined by plating $10 \mu 1$ of the suspension of $10^{-5}-10^{-8}$ dilutions on MacConkey Agar.

Spore-forming bacteria, including clostridia, were isolated by seeding $10 \mu \mathrm{l}$ of $10^{-3}-10^{-5}$ and $10^{-7}$ dilutions on Wilson-Blair agar. After $48 \mathrm{~h}$ of incubation, the number of black colonies in the agar depth was calculated and formation of the gas separating the nutrient medium was recorded.

Counting of all types of microorganisms was carried out according to the formula: CFU/g $=a \times b \times c$, where: $a$ stands for the number of colonies grown on the nutrient medium; $b$ stands for dilution coefficient dose (when plating $100 \mu 1, a=10$; when seeding $50 \mu 1, a=5$; when plating $10 \mu 1, a=100$ ); and $c$ stands for dilution factor.

Identification of isolated microorganisms was performed using biochemical test systems ANAERO-23, ENTERO-24, NEFERM-test, Candida-23, STAPHYtest 16, and STREPTOtest 24 (Erba Lachema s.r.o., Czech Republic).

Statistical analysis. The experiments were performed in triplicate. For the mathematical analysis of the data, licensed software SPSS 17.0 was used. Parametric results were reported as means with $\mathrm{SD}$. The normality of distribution was determined using the Lilliefors criterion. In the group differences before and after the intervention were evaluated using the Wilcoxon rank-sum test. The differences between the groups were evaluated using the Mann-Whitney $\mathrm{U}$ test. $P<0.05$ was considered significant. Correlation relationships were determined using the Pearson coefficient.

\section{Results and Discussion}

Under the influence of different ingredients potential components of the new generation functional foods - body weight of the experimental animals significantly decreased $(P<0.05)$ in all groups except the control one, where it grew by $(20 \pm 4) \mathrm{g}$, and the fourth group of rats that followed the fermented milk drink diet without plant components, where we noted an increased body weight $(P<0.05)$ by $(15 \pm 4) \mathrm{g}$ (Fig. 1). LDL significantly decreased $(P<0.05)$ under the influence of lactobacilli, 15\% apple pectin concentrate, lignins, and sauerkraut juice, while in other experimental groups there were no significant changes observed $(P>0.05)$ compared to the control group where this parameter significantly increased $(P<0.05)$, namely 2.5 times (Fig. 2, B).

As a result of the introduction of the diets we developed, total lipid content significantly decreased $(P<0.001)$ in all animal groups except three groups: one of them being the control group, where a significant increase $(P<0.01)$ in the total lipid content was noted, and in two experimental groups of animals consuming apple pectin and lignin (Fig. 2, C). Cho- 


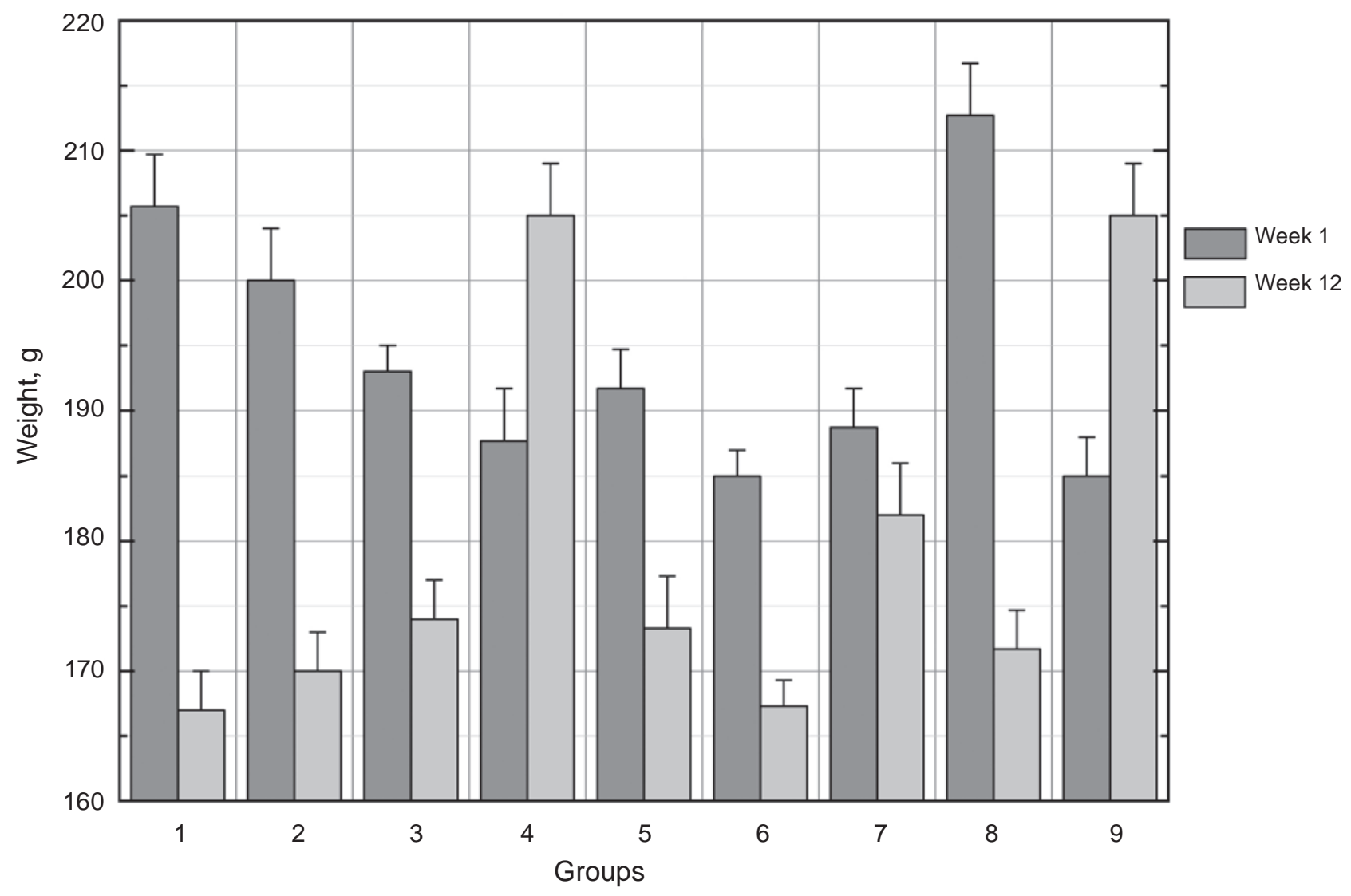

Fig. 1. Rats' body weight changes during the long-term experiment (for 12 weeks). Group 1 - suspension of lactobacilli (L. casei IMB B-7412, L. plantarum IMB B-7414, L. paracasei IMB B-7483 and L. plantarum KR1); Group 2 - blueberries juice; Group 3 - sour dairy drink based on the strains of lactobacilli (L. paracasei IMB B-7483, L. casei IMB B-7412, L. plantarum IMB B-7414 and L. plantarum KR-1) with the blueberries juice; Group 4 - sour dairy drink based on the strains of lactobacilli (L. paracasei IMB B-7483, L. casei IMB B-7412, L. plantarum IMB B-7414 and L. plantarum KR-1) without plant components; Group 5 - fermented cabbage juice with L. casei IMB B-7412, L. plantarum IMB B-7414; Group 6 - persimmon juice; Group 7 lignin; Group 8 - apple-pectin concentrate 15\%; Group 9 - control group

lesterol reduction $(P<0.05)$ occurred in all experimental groups of animals (Fig. 2, D). Interestingly, only in case of apple pectin consumption triglyceride concentration decreased (Fig. 2, A). A decrease in the concentration of blood urea from $(3.57 \pm 0.03)$ $\mathrm{mmol} / \mathrm{l}$ to $(0.9 \pm 0.01) \mathrm{mmol} / \mathrm{l}(P<0.01)$ was observed only in the group of animals following a diet enriched with probiotic bacterial strains (Fig. 3, A). Glucose content decreased significantly $(P<0.01)$ under the effect of blueberry juice and fermented milk drink without plant components (Fig. 3, C), but not when fermented milk drink with blueberry extract was used separately. An increase in calcium from $(0.68 \pm 0.03) \mathrm{mmol} / \mathrm{l}$ to $(0.79 \pm 0.05) \mathrm{mmol} / \mathrm{l}$ $(P<0.01)$ was observed under the composition of fermented milk drink without plant components.
When using all other diets, a decrease in calcium levels was observed (Fig. 3, B).

Despite the increasing weight of animals in the control group and animals consuming fermented milk drink with lactobacilli without plant components, these two groups significantly differed in other lipid profile indices. In contrast to the control group, animals consuming fermented milk drink without plant components had an improvement in almost all registered biochemical parameters (including a slight decrease in total blood plasma lipids and a similar increase in calcium levels).

In the study, we used elderly white rats with obesity caused by age-related changes and feeding them high-fat diet. Existing at the beginning of the experiment and progressive metabolic disorders led 


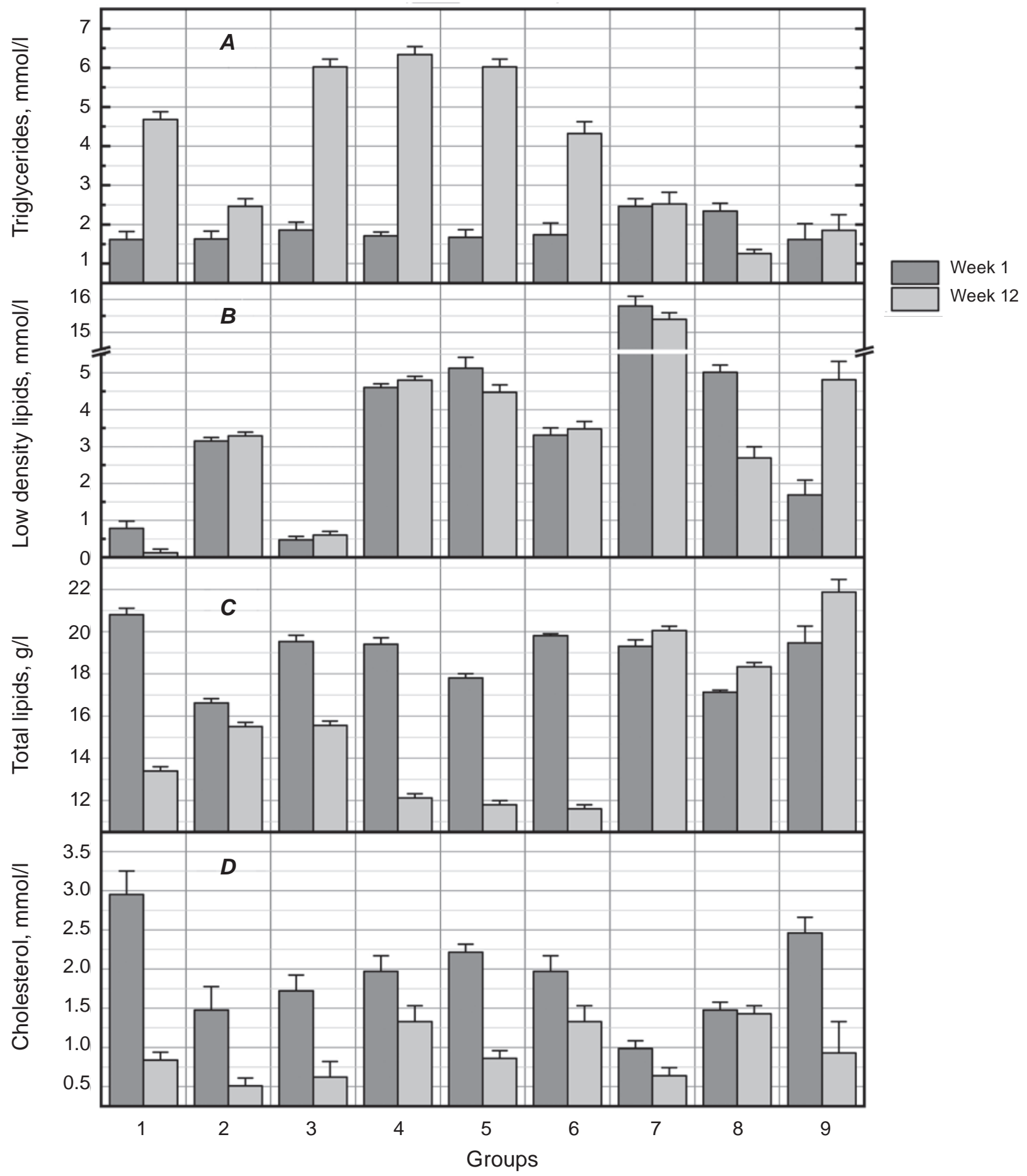

Fig. 2. Changes in the levels of biochemical parameters of rats at 1 and 12 weeks: $\boldsymbol{A}$ - triglycerides; $\boldsymbol{B}-L D L$; $\boldsymbol{C}$ - total lipids; $\mathbf{D}$ - cholesterol

to an increase in the weight of animals in the control group in the absence of treatment and resulted in a difference between the biochemical parameters of the rats' blood before and after the experiment. The increase in weight of experimental animals of group 4 is explained by the fact that long-term con- sumption of lactic acid products (on the example of our studied fermented beverage - fermented milk product with selected LAB strains) leads to weight gain due to their high fat and caloric content. Therefore, when prescribing or selecting products, even a healthy diet should be guided by their defined norms, 


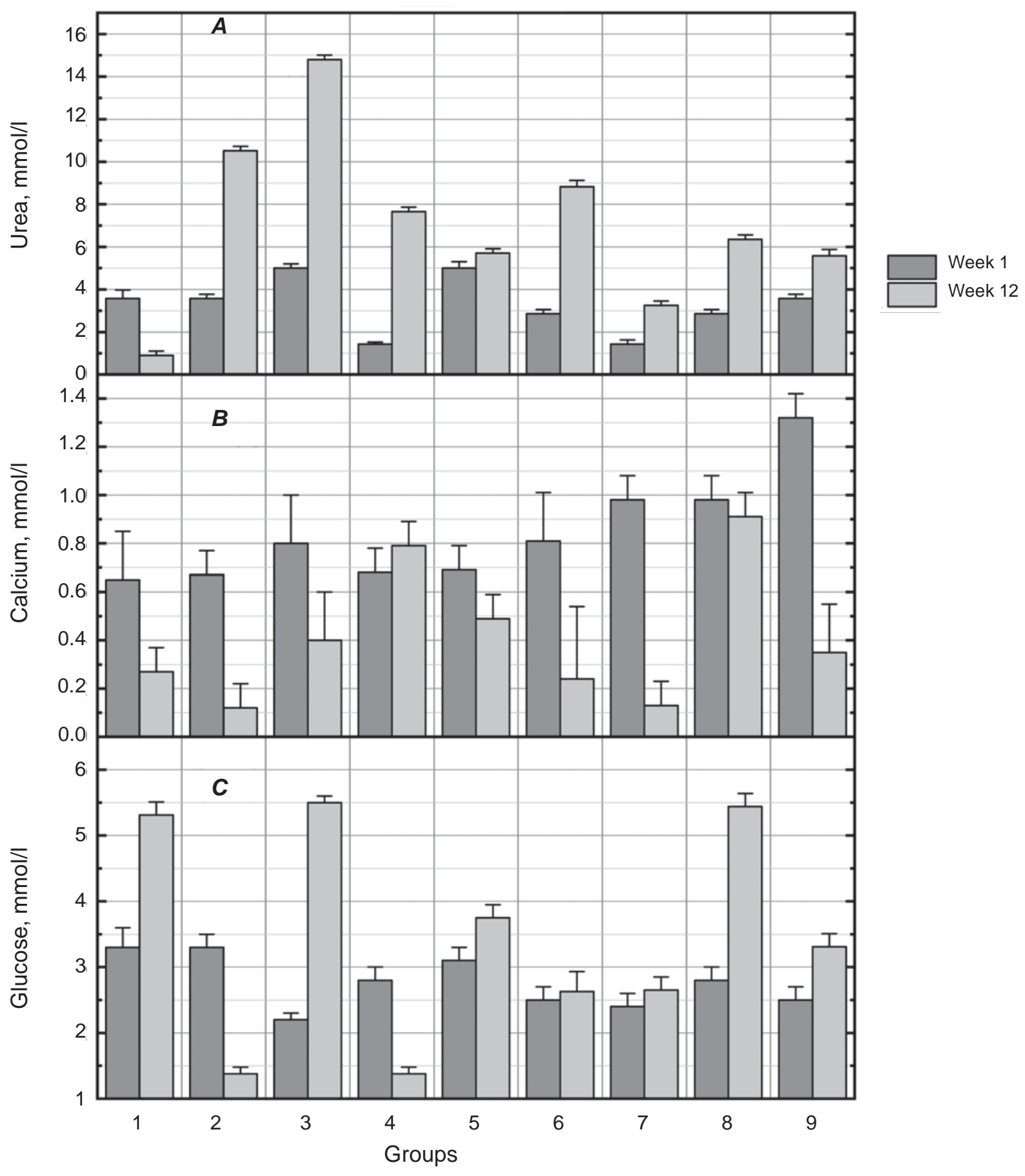

Fig. 3. Changes in the content of the biochemical parameters of rats at 1 and 12 weeks: $\boldsymbol{A}$ - urea; $\boldsymbol{B}$-calcium; C-glucose

limited amount or fat content, and to ensure a balanced diet, it is necessary to predict the effects of exposure, which can be provided by our correlations of prognostic corrections of the microbiome.

Our study demonstrated that animals can be overweight not only because of increasing levels of opportunistic microorganisms such as Staphylococcus nepalensis and Enterococcus faecalis, but also because of the high level of the probiotic strain Bifidobacterium breve. Confirmed results of the ability of blueberry juice (from 3.3 to $1.38 \mathrm{mmol} / \mathrm{l}$ ) and developed fermented milk drink (from 2.8 to $1.38 \mathrm{mmol} / \mathrm{l}$ ) to regulate blood glucose levels in vivo may have a prognostic value for recommending this diet to patients with type 2 diabetes. 
During the whole study we observed the following changes in rats' gut microbiota under the influence of different diets. A consistently high level of lactic acid and other beneficial bacteria and a decreasing level of opportunistic microorganisms were detected in almost all experimental groups compared to the control group.

Consumption of almost all of the developed food components (diets) caused a decrease in the concentration of E. faecalis and different Staphylococcus species compared to that in the control group. The level of Klebsiella pneumoniae and Morganella morganii decreased significantly under the effect of blueberry juice. The level of $B$. subtilis remained almost unchanged during the whole experiment under the influence of the test samples based on plant extracts, plant pectins, and lignins.

Oral administration of lactobacillus strains suspension (L. casei IMB B-7412, L. plantarum IMB B-7414, L. paracasei IMB B-7483, and L. plantarum KR-1) demonstrated an antagonistic activity against Staphylococcus aureus, Peptostreptococcus anaerobius, and E. faecalis and led to a decrease in Escherichia coli and Enterobacter cloacae levels in obese rats during the whole experiment (Fig. 4, A).

The concentration of commensal K. pneumoniae, M. morganii, E. coli, Actinomyces naeslundii, and Bacteroides significantly decreased under the influence of a blueberry juice-based diet. In this study group, complete elimination of Streptococcus parvulus and increase in E. faecalis and staphylococci were observed (Fig. 4, B).

Reduction in opportunistic microorganisms and increase in beneficial microbiota indicated a positive effect of consumption of the developed fermented milk product with blueberry juice. Throughout the study, we observed an increase in commensal lactobacilli, elimination of Staphylococcus spp. and E. faecalis, and a decreased concentration of E. coli in this experimental group compared to the control group (Fig. 5, A).

It was demonstrated that the 12 -weeks oral administration of fermented milk drink with strains of lactobacilli (L. paracasei IMB B-7483, L. casei IMB B-7412, L. plantarum IMB B-7414, and L. plantarum KR-1) eliminated M. morganii and E. faecalis and reduced E. coli and Actinomyces israelii concentrations in obese rats (Fig. 5, B).

In this study, increased commensal lactobacilli concentration, partial elimination of $E$. coli and Bacillus subtilis, as well as complete elimination of cocci were observed under the influence of sauerkraut juice (Fig. 6, A).

It should be noted that persimmon juice, in case of long-term oral administration to animals, demonstrated a significant antagonistic effect against Staphylococcus cohnii and led to a decrease in the levels of E. coli, Proteus mirabilis, E. cloacae, and $E$. faecalis. In addition, consistently high levels of microorganisms, such as Lactobacillus acidophilus, Bifidobacterium longum, and B. subtilis ( $(5 \pm 0.3)$ $\times 10^{8} \mathrm{CFU} / \mathrm{g}$ ), were observed in case of persimmon juice consumption compared to the control group (Fig. 6, B).

As most vegetables and fruits contain dietary fiber (pectin, lignin, cellulose, and hemicellulose), which is a natural enterosorbent and can affect quantitative and qualitative composition of gut microbiota, we investigated apple pectin and lignin effect in a chronic experiment on obese rats.

The reduction in enterococci, $B$. subtilis, E. coli, and P. mirabilis with a slight increase in commensal lactobacilli concentration were observed under the influence of lignin (Fig. 7, A).

Oral administration of pectin-based diet (applepectin concentrate) demonstrated complete elimination of E. faecalis and a decrease in the concentration of commensal Bifidobacterium, staphylococci, E. coli, and B. subtilis (Fig. 7, B).

Changes in gut microbiota of the control group of animals demonstrated a decrease in the concentration of $E$. faecalis and $B$. subtilis, as well as an increase in the concentration of $P$. mirabilis (Fig. 8).

The reduction in Lactobacillus spp., B. subtilis, and $P$. mirabilis in the gut microbiome may serve as a biomarker of triglyceride increase and LDL and cholesterol reduction (and vice versa). The increase in $B$. breve and $B$. subtilis is a biomarker of decreased plasma calcium (and vice versa).

In order to confirm the possibility of using these microbial and biochemical parameters as biomarkers, we searched for correlation between them and classical disease signs, both at the beginning of the study and after it.

In our study, such an indicator of lipid metabolism as triglycerides closely correlates with LDL (Pearson correlation coefficient is $r=0.7506$ ) and Lactobacillus spp. $(r=0.7130)$ in the gut microbiome of rats. In turn, LDL inversely correlates with cholesterol $(r=-0.6772)$, while the inverse correlation of cholesterol with the triglycerides $(r=-0.7402)$ was also observed. Overweight, as a baseline indicator 


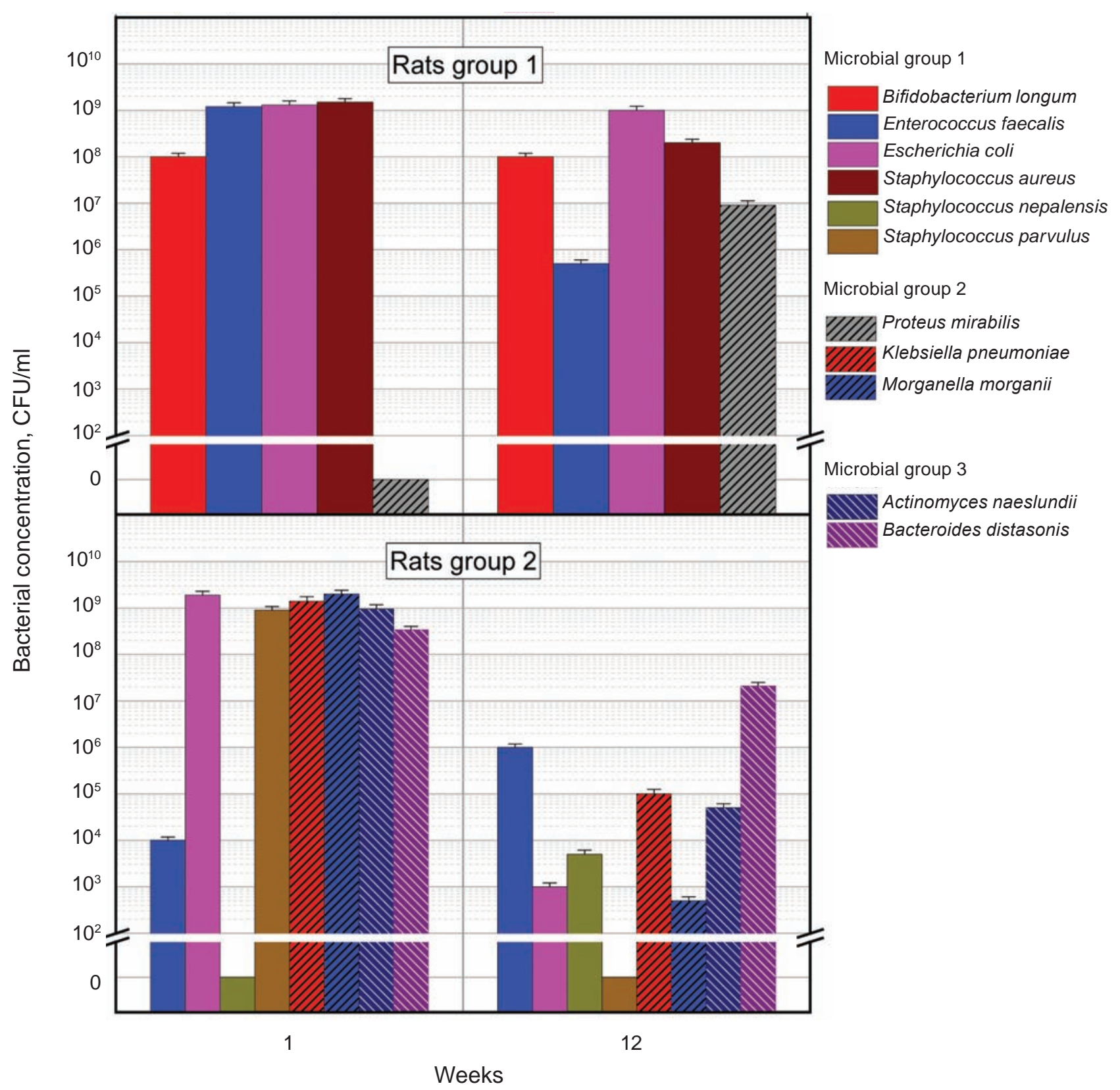

Fig. 4. Changes in gut microbiota of rats in the groups 1 and 2 at 1 and 12 weeks in a chronic experiment

of abdominal fat distribution, directly correlates with B. breve $(r=1,000)$ and $S$. nepalensis $(r=0.9244)$.

A correlation was found between $B$. breve and E. faecalis $(r=0.9917)$ as well as between $E$. faecalis and $S$. nepalensis $(r=1,000)$. In its turn, S. nepalensis inversely correlates with $B$. breve $(r=-0.5379)$. Correlation was also found between $P$. mirabilis and Lactobacillus spp. $(r=0.6776)$. In this study, the change in the ratio of $E$. coli isolates with typical and atypical enzymatic activity was investigated, with the number of isolates with atypical enzymatic activity predominating. It is interesting that the concentration of lactose-negative $E$. coli strains correlates with the number of lactobacilli $(r=0.7608)$ and Staphylococcus spp. $(r=-0.7608)$ while Lactobacillus reuteri correlates with Staphylococcus spp. $(r=0.7456)$.

We also observed correlation between $L$. acidophilus and S. aureus $(r=0.9979)$ in turn, S. aureus correlated with Staphylococcus epidermidis $(r=-0.8520)$, and S. epidermidis inversely correlated with $L$. acidophilus $(r=-1,000)$. A correlation be- 


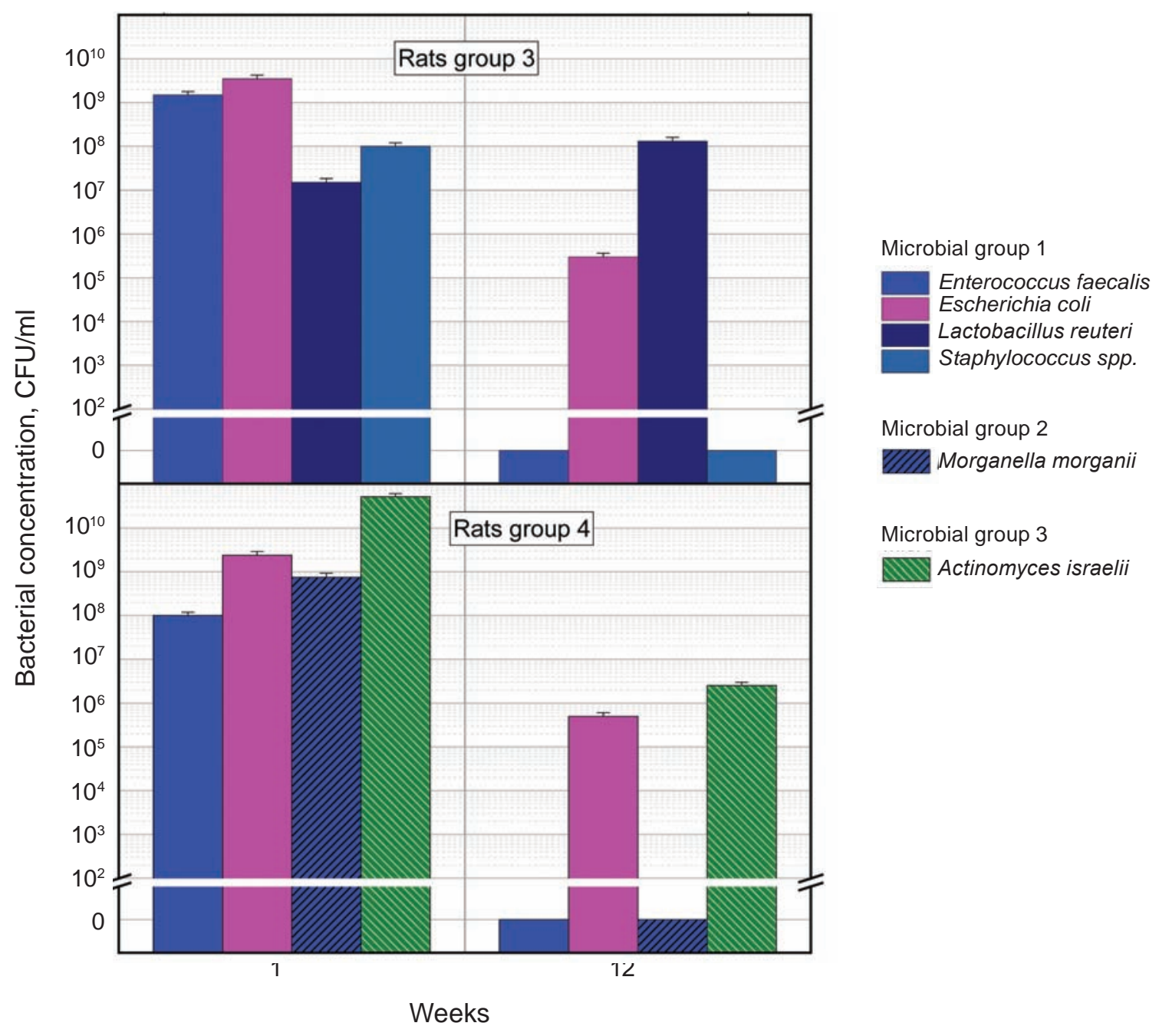

Fig. 5. Changes in gut microbiota of rats in the groups 3 and 4 at 1 and for 12 weeks in a chronic experiment

tween $P$. anaerobius and E. cloacae was established $(r=0.6727)$.

In this study we detected correlation between Bacteroides distasonis and M. morganii $(r=0.6811)$ in turn, $M$. morganii correlated with $K$. pneumoniae $(r=0.6811)$ and $K$. pneumoniae was negatively correlated with $B$. distasonis $(r=1,000)$ while A. naeslundii $(r=1,000)$ and $A$. naeslundii negatively correlated with $S$. parvulus $(r=-1,000)$. Negative correlation of B. distasonis with $S$. parvulus $(r=-1,000)$ and $S$. parvulus with $K$. pneumoniae $(r=1,000)$ was also established.

We found a direct correlation between the amount of $L$. acidophilus and S. aureus in the intestinal contents of rats using the tested products. Other scientists have studied that in obesity and irritable bowel syndrome observed the growth of op- portunistic pathogens, including staphylococci and a decrease in lactobacilli [34].

Also we can say that blood glucose is an ambiguous indicator. Today, there is evidence that different strains of different LABs regulate blood glucose levels differently - from no effect to a decrease or increase in serum levels. In particular, according to the European Journal of Clinical Nutrition [35], men were given lactobacilli-based yogurt (L. acidophilus) for three weeks and as a result the level of HDL cholesterol, triglycerides and blood glucose in the serum remained unchanged.

Another study shows that the strain of Lactobacillus rhamnosus causes a decrease in glucose levels [36]. There is a study according to which the level of glucose depends on the content of calcium ions and its reduction should not be interpreted unambiguous- 


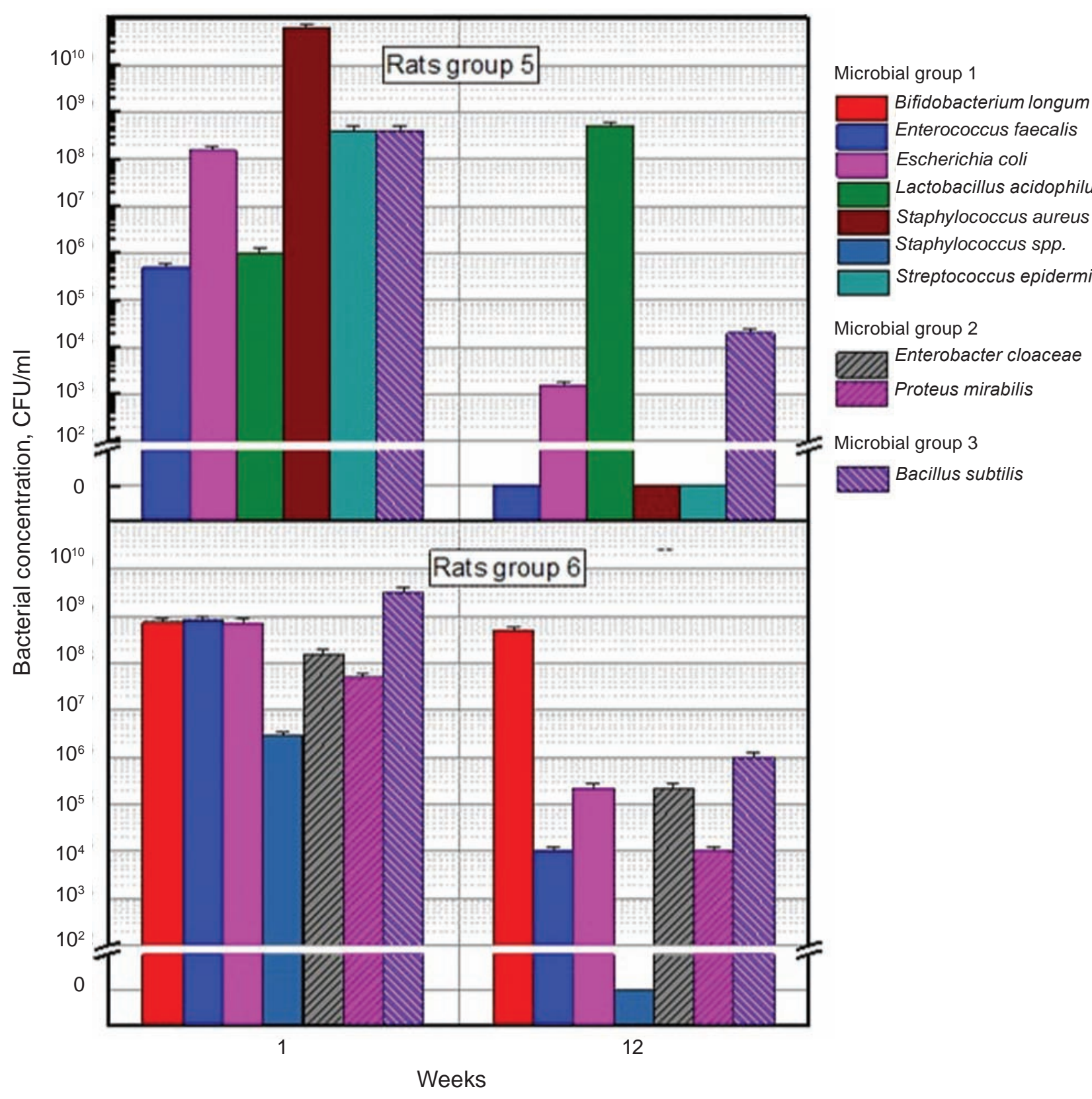

Fig. 6. Changes in gut microbiota of rats in the groups 5 and 6 at 1 and 12 weeks in a chronic experiment

ly [37]. Therefore, to assess the effectiveness against obesity, we first considered the expected (desired) changes in lipid metabolism.

In fact, there are virtually no publications linking biochemical and microbial indicators. These parameters should be correlated with biochemical and immune parameters. Our goal was a comprehensive study of all indicators to determine dynamic changes. This direction was initiated by us and similar approaches were developed by us in the corresponding articles [38].
The results of our study demonstrated positive effects of separate components as well as the novel functional food itself, namely fermented milk drink with strains of lactobacilli and blueberry juice. Apparently, this is due to the fact that probiotic strains of lactobacilli and bifidobacteria create unfavorable conditions for pathogens' colonization by decreasing their adhesive features. Additionally, probiotic strains and plant extracts have the ability to adjust and stimulate the beneficial gut microbiota of the experimental animals. 


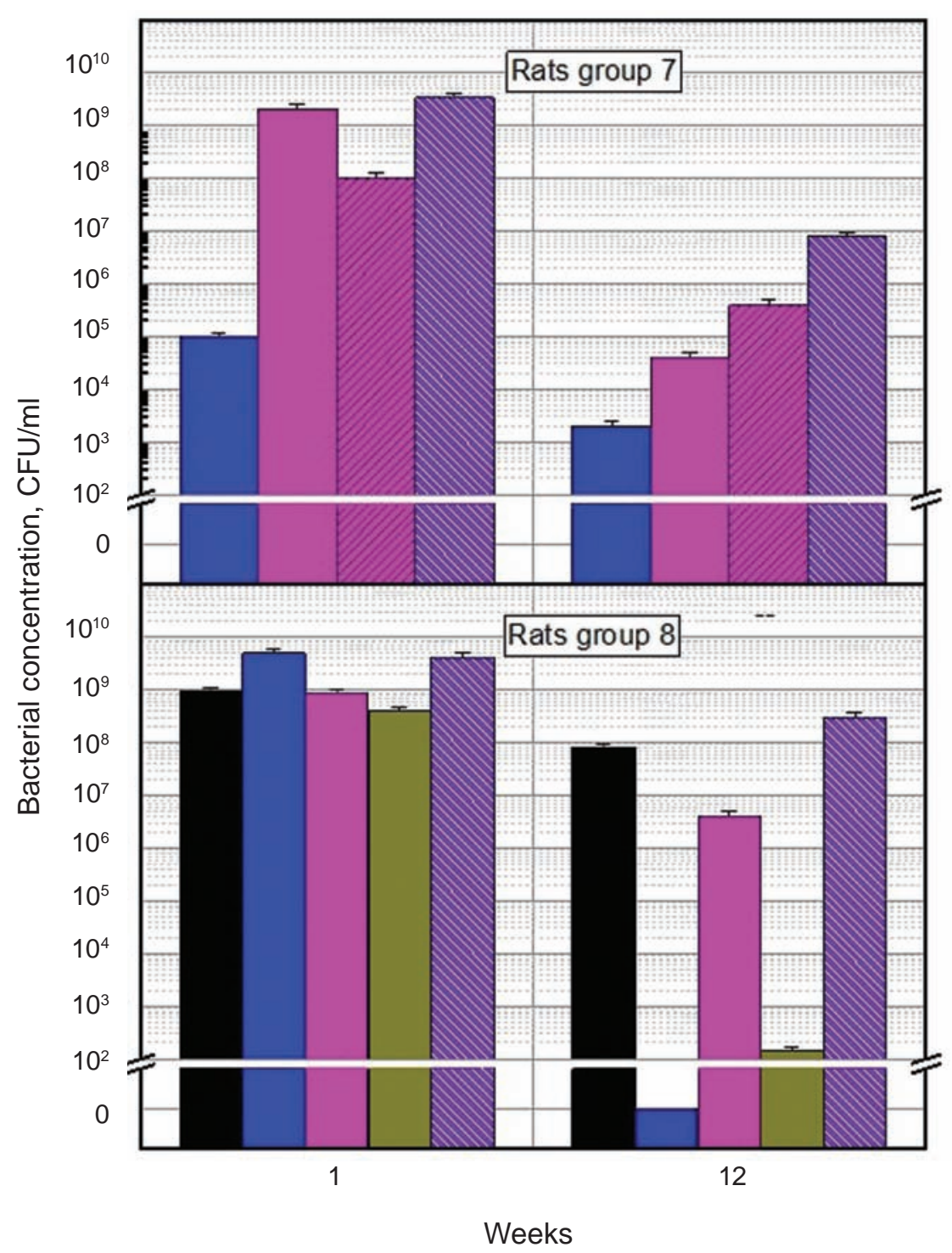

Microbial group 1

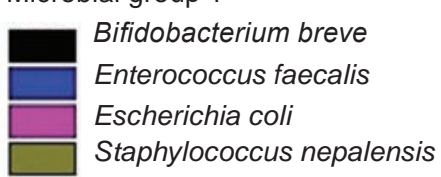

Microbial group 2

DID Proteus mirabilis

Microbial group 3

Bacillus subtilis

Fig. 7. Changes in gut microbiota of rats in the groups 7 and 8 at 1 and 12 weeks in a chronic experiment

While analyzing the results of this study, it can be argued that the suspension of lactobacilli L. paracasei IMB B-7483, L. casei IMB B-7412, L. plantarum IMB B-7414, and L. plantarum KR-1 demonstrated the best hypocholesterolemic activity since the long-term oral administration of suspension of these strains led to a decrease in cholesterol levels from 2.95 to $0.84 \mathrm{mmol} / \mathrm{l}$.

As the glucose level in the serum of obese animals decreased due to oral administration of blueberry juice, as well as fermented milk drink with strains of L. casei IMB B-7412, L. plantarum IMB B-7414, L. paracasei IMB B-7483, and L. plantarum KR-1, these particular components can be offered to patients with type 2 diabetes.
It is interesting that the use of suspensions of lactobacilli $L$. paracasei IMB B-7483, L. casei IMB B-7412, L. plantarum IMB B-7414, and L. plantarum KR-1, sauerkraut juice (enriched with strains of L. plantarum IMB B-7414 and L. casei IMB B-7412), $15 \%$ apple pectin concentrate, and lignin cause a decrease in LDL levels. However, it should be noted that a $15 \%$ apple pectin concentrate has the highest hypolipidemic activity since the long-term oral administration of this component leads to a decrease in not only LDL, but also triglycerides and cholesterol. That is why these components can be used to prevent atherosclerosis and cardiovascular disease. 


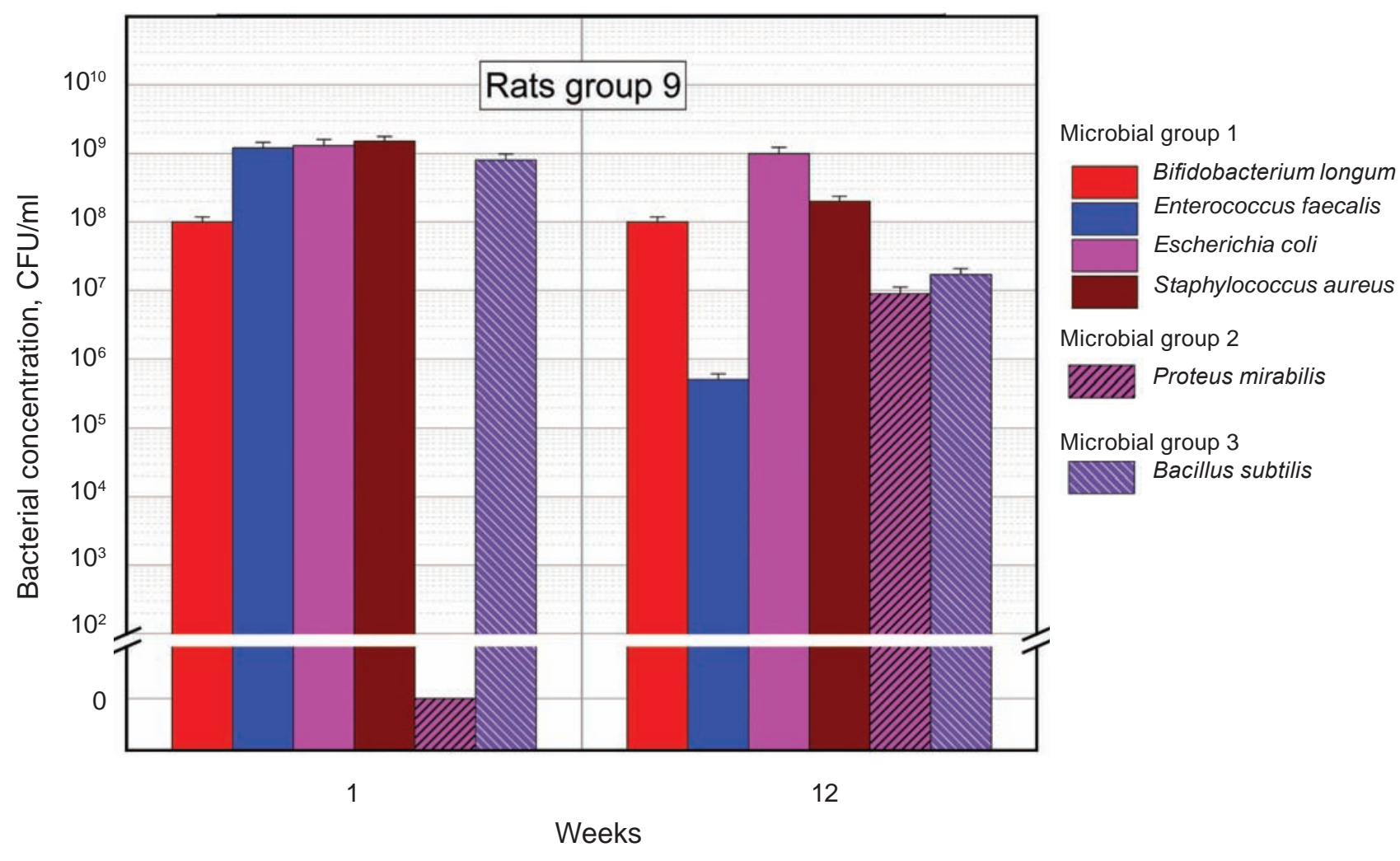

Fig. 8. Changes in gut microbiota of rats in the group 9 (control group) at 1 and 12 weeks in a chronic experiment

Conclusion. The results obtained during the study, as well as the correlation between the changes in key representatives of gut microbiota and values of biochemical indicators of the organism's state give the possibility to develop the new generation functional foods able to regulate gut microbiota balance and prevent the development of diet-associated pathologies.

Conflict of interest. Authors have completed the Unified Conflicts of Interest form at http://ukrbiochemjournal.org/wp-content/uploads/2018/12/ coi_disclosure.pdf and declare no conflict of interest.

Funding. This work is funded under the State governmental budget of Ministry of Education and Science, Topic: "Composite biological products from microorganisms, plants and nanocompounds” Registration number 0113U002369.

\section{ПЕРСОНІФІКОВАНА ДІЕТА ПОКРАЩУС МІКРОБІОТУ КИШЕЧНИКА ТА МЕТАБОЛІЗМ ЩУРІВ 3 ОЖИРІННЯМ}

\author{
В. В. Баті $i^{1 凶}$, Т. В. Мелешко ${ }^{1}$ О. В. Паллаг ${ }^{1}$, \\ I. П. Заячук ${ }^{2}$ Н. В. Бойко
}

${ }^{1}$ НДНЦ молекулярної мікробіології та імунології слизових оболонок, Ужгородський національний університет, Україна; ${ }^{2}$ Кафедра фізіології та патофізіології, Ужгородський національний університет, Україна;

$\unrhd_{\text {e-mail: victoria.bati@uzhnu.edu.ua }}$

Сучасні дослідження мікробіому людини уможливлюють конструювання функціональних продуктів харчування нового покоління, здатних регулювати кишкову мікробіоту та біохімічний статус індивідууму. Метою дослі- 
дження було з'ясувати вплив індивідуально розробленого харчування на мікробіоту кишечника та показники метаболізму в щурів. Безпородних щурів із ожирінням було випадковим чином розділено на дев'ять груп $(n=12)$ залежно від типу перорально вживаних протягом трьох місяців інгредієнтів харчування. Визначали співвідношення основних груп кишкових коменсальних мікроорганізмів, а також ліпідний профіль та вміст глюкози, сечовини, кальцію у сироватці крові тварин. Встановлено зниження рівня холестеролу в сироватці крові дослідних тварин після випоювання їм суспензії лактобактерій, соку чорниці, кисломолочного напою на основі лактобактерій, кисломолочного напою 3 соком чорниці, квашеної капусти. У більшості випадків кишковий мікробіом експериментальних тварин характеризувався стабільно високим рівнем лакто- та інших корисних бактерій та зменшенням кількості умовно-патогенних мікроорганізмів наприкінці експерименту порівняно $з$ тваринами контрольної групи. На основі одержаних даних нами вперше запропоновано принципи створення функціональних продуктів нового покоління шляхом синергідного поєднання компонентів їстівних рослин (що діють, як пребіотики) та мікроорганізмів (що діють, як пробіотики) з метою їх прогностичного та персоніфікованого застосування для попередження виникнення некомунікативних захворювань, шляхом спрямованої корекції мікробіому кишечника макроорганізму, а відтак і його біохімічного статусу.

К л ю чо в і с лов а: функціональні продукти харчування, ліпідний профіль, холестерол, ожиріння, мікробіота кишечника, пребіотичні та пробіотичні компоненти.

\section{References}

1. D'Argenio V, Salvatore F. The role of the gut microbiome in the healthy adult status. Clin Chim Acta. 2015; 451(Pt A): 97-102.

2. Dickerson F, Severance E, Yolken R. The microbiome, immunity, and schizophrenia and bipolar disorder. Brain Behav Immun. 2017; 62: 46-52.

3. Ascher S, Reinhardt C. The gut microbiota: An emerging risk factor for cardiovascular and cerebrovascular disease. Eur J Immunol. 2018; 48(4): 564-575.
4. Virgin HW, Todd JA. Metagenomics and personalized medicine. Cell. 2011; 147(1): 44-56.

5. Round JL, Mazmanian SK. Inducible Foxp3+ regulatory T-cell development by a commensal bacterium of the intestinal microbiota. Proc Natl Acad Sci USA. 2010; 107(27): 12204-12209.

6. Atarashi K, Tanoue T, Shima T, Imaoka A, Kuwahara T, Momose Y, Cheng G, Yamasaki S, Saito T, Ohba Y, Taniguchi T, Takeda K, Hori S, Ivanov II, Umesaki Y, Itoh K, Honda K. Induction of colonic regulatory $\mathrm{T}$ cells by indigenous Clostridium species. Science. 2011; 331(6015): 337-341.

7. Isolauri E, Rautava S, Collado MC, Salminen S. Role of probiotics in reducing the risk of gestational diabetes. Diabetes Obes Metab. 2015; 17(8): 713-719.

8. Sanz Y, Santacruz A, Gauffin P. Gut microbiota in obesity and metabolic disorders. Proc Nutr Soc. 2010; 69(3): 434-441.

9. Furet JP, Kong LC, Tap J, Poitou C, Basdevant A, Bouillot JL, Mariat D, Corthier G, Doré J, Henegar C, Rizkalla S, Clément K. Differential adaptation of human gut microbiota to bariatric surgery-induced weight loss: links with metabolic and low-grade inflammation markers. Diabetes. 2010; 59(12): 3049-3057.

10. Lloyd-Price J, Abu-Ali G, Huttenhower C. The healthy human microbiome. Genome Med. 2016; 8(1): 51.

11. Sassone-Corsi M, Raffatellu M. No vacancy: how beneficial microbes cooperate with immunity to provide colonization resistance to pathogens. $J$ Immunol. 2015; 194(9): 4081-4087.

12. Pat. No 90789 A Technique for the prevention of purulent complications and wound infection after tooth extraction with bacterial suspension based on Bacillus subtilis 090 / Petrov VO, Rusyn VI, Boiko NV. Publ. 10.06.2014 Bul. No 11. (In Ukrainian).

13. Pat. No 93301. Composite biological product for the treatment of inflammation of periodontal tissues and correction of associated gastroduodenal disorders of the intestine in children / Melnyk VS, Diachuk EY, Bati VV, Levchuk OB, Boiko NV. Publ. 25.09.2014, Bul. No 18. (In Ukrainian).

14. Ercolini D, Fogliano V. Food Design To Feed the Human Gut Microbiota. J Agric Food Chem. 2018; 66(15): 3754-3758. 
15. Kasubuchi M, Hasegawa S, Hiramatsu $T$, Ichimura A, Kimura I. Dietary gut microbial metabolites, short-chain fatty acids, and host metabolic regulation. Nutrients. 2015; 7(4): 2839-2849.

16. Donohoe DR, Garge N, Zhang X, Sun W, O'Connell TM, Bunger MK, Bultman SJ. The microbiome and butyrate regulate energy metabolism and autophagy in the mammalian colon. Cell Metab. 2011; 13(5): 517-526.

17. Desbonnet L, Clarke G, Traplin A, O'Sullivan O, Crispie F, Moloney RD, Cotter PD, Dinan TG, Cryan JF. Gut microbiota depletion from early adolescence in mice: Implications for brain and behaviour. Brain Behav Immun. 2015; 48: 165173.

18. Enck P, Zimmermann K, Rusch K, Schwiertz A, Klosterhalfen S, Frick JS. The effects of maturation on the colonic microflora in infancy and childhood. Gastroenterol Res Pract. 2009; 2009: 752401.

19. Trichopoulou A, Naska A, Orfanos P, Trichopoulos D. Mediterranean diet in relation to body mass index and waist-to-hip ratio: the Greek European Prospective Investigation into Cancer and Nutrition Study. Am J Clin Nutr. 2005; 82(5): 935-940.

20. Garcia-Mantrana I, Selma-Royo M, Alcantara C, Collado MC. Shifts on Gut Microbiota Associated to Mediterranean Diet Adherence and Specific Dietary Intakes on General Adult Population. Front Microbiol. 2018; 9: 890.

21. Ivanov II, Atarashi K, Manel N, Brodie EL, Shima T, Karaoz U, Wei D, Goldfarb KC, Santee CA, Lynch SV, Tanoue T, Imaoka A, Itoh $\mathrm{K}$, Takeda $\mathrm{K}$, Umesaki $\mathrm{Y}$, Honda $\mathrm{K}$, Littman DR. Induction of intestinal Th17 cells by segmented filamentous bacteria. Cell. 2009; 139(3): 485-498.

22. Ivanov II, Frutos RdeL, Manel N, Yoshinaga K, Rifkin DB, Sartor RB, Finlay BB, Littman DR. Specific microbiota direct the differentiation of IL-17-producing T-helper cells in the mucosa of the small intestine. Cell Host Microbe. 2008; 4(4): 337-349.

23. Mazmanian SK, Round JL, Kasper DL. A microbial symbiosis factor prevents intestinal inflammatory disease. Nature. 2008; 453(7195): 620-625.

24. Round JL, Mazmanian SK. Inducible Foxp3+ regulatory T-cell development by a commensal bacterium of the intestinal microbiota. Proc Natl Acad Sci USA. 2010; 107(27): 12204-12209.

25. McDermott AJ, Huffnagle GB. The microbiome and regulation of mucosal immunity. Immunology. 2014; 142(1): 24-31.

26. Mazmanian SK, Round JL, Kasper DL. A microbial symbiosis factor prevents intestinal inflammatory disease. Nature. 2008; 453(7195): 620-625.

27. Wieland Brown LC, Penaranda C, Kashyap PC, Williams BB, Clardy J, Kronenberg M, Sonnenburg JL, Comstock LE, Bluestone JA, Fischbach MA. Production of $\alpha$-galactosylceramide by a prominent member of the human gut microbiota. PLoS Biol. 2013; 11(7): e1001610.

28. Kim H, Kim DH, Seo KH, Chon JW, Nah SY, Bartley GE, Arvik T, Lipson R, Yokoyama W. Modulation of the intestinal microbiota is associated with lower plasma cholesterol and weight gain in hamsters fed chardonnay grape seed flour. J Agric Food Chem. 2015; 63(5): 1460-1467.

29. Deller S, Canto A, Brown L. Food access, local foods, and community health. Community Dev. 2017; 48(5): 657-680.

30. Bati VV, Boyko NV. The biological properties of lactobacilli strains isolated from food of plant origin and edible plants. ScienceRise. 2016; 8(1(25)): 6-14. (In Ukrainian).

31. Bati VV, Boyko NV. Microbiological analysis of sauerkraut in the process of its fermentation according to the traditional and modernized technologies. Microbiol Biotechnol. 2017; (2(38)): 90-100.

32. Bati VV, Boyko NV. Novel functional food for prevention of non-communicable diseases. Biol Stud. 2019; 13(1): 71-84.

33. Buettner R, Parhofer KG, Woenckhaus M, Wrede CE, Kunz-Schughart LA, Schölmerich J, Bollheimer LC. Defining high-fat-diet rat models: metabolic and molecular effects of different fat types. J Mol Endocrinol. 2006; 36(3): 485-501.

34. Grygoruk GV, Myshchuk VG, Tserpiak NV. Changes in gut microbiota and blood lipid profile in patients with irritable bowel syndrome in association with obesity. Bukovin Med Herald. 2019; 23(1(89)): 32-38. (In Ukrainian).

35. Schaafsma G, Meuling WJ, van Dokkum W, Bouley C. Effects of a milk product, fermented by Lactobacillus acidophilus and with fructo- 
oligosaccharides added, on blood lipids in male volunteers. Eur J Clin Nutr. 1998; 52(6): 436440.

36. Farida E, Nuraida L, Giriwono PE, Jenie BSL. Lactobacillus rhamnosus Reduces Blood Glucose Level through Downregulation of Gluconeogenesis Gene Expression in Streptozotocin-Induced Diabetic Rats. Int $J$ Food Sci. 2020; 2020: 6108575.
37. Bartlett PJ, Gaspers LD, Pierobon N, Thomas AP. Calcium-dependent regulation of glucose homeostasis in the liver. Cell Calcium. 2014; 55(6): 306-316.

38. Golubnitschaja O, Topolcan O, Kucera R, Costigliola V, EPMA. $10^{\text {th }}$ Anniversary of the European Association for Predictive, Preventive and Personalised (3P) Medicine - EPMA World Congress Supplement 2020. EPMA J. 2020; 11(Suppl 1): 1-133. 